\title{
Phonemic Awareness: A Core Phonological Skill in Learning English
}

\section{Pauline Bunce \\ Cyril Jackson Senior Campus, Perth, Australia}

\section{Reference Data:}

Bunce, P. (2020). Phonemic awareness: A core phonological skill in learning English. In P. Clements, A. Krause, \& R. Gentry (Eds.), Teacher efficacy, learner agency. Tokyo: JALT. https://doi.org/10.37546/JALTPCP2019-37

Well-developed phonological awareness skills are central to the ultimate achievement of fluent alphabet-scripted literacy. This workshop at JALT2019 was focused on the benefits that can flow from short bursts of phonemic awareness activities in daily English classes, revolving around a sequence of nonprint activities that have been designed to heighten learners' auditory reception and oral production of the smallest units of sound in the English language. These sounds, or phonemes, may or may not be present in learners' primary languages. A sharpened awareness of individual phonemes and the ability to isolate and manipulate them can have the potential to open up the sound elements of alphabetic written text to those biscriptal learners who may have previously relied on the visual memorisation of spelling patterns. Phonemic insights into the alphabetic written code are especially important for learners with established literacy in the Chinese or Japanese written script.

発達した音䫓認識スキルはは、アルファベット表記テキストを読み書きする優れた能力を最大限習得するのに重要であ る。ALT2019のこのワークショシプでは、日々の英語のクラスで音素認識活動を大量に行うことから生じる効果に焦点を当て。

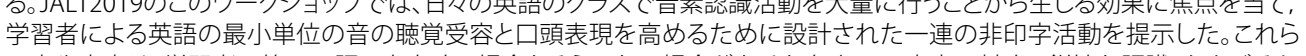

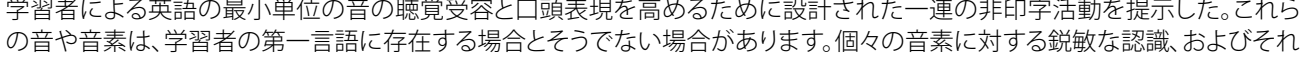

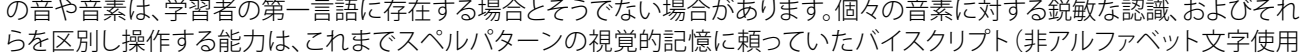
地域の) 学習者に、アルフアベット表記テキストの音声要素の理解への゙道を切り開ぐ可能性がある。アルフフアベットの記述 一ドに対する音䫓的洞察は、中国語や日本語の記述形式に慣れている学習者にとって特に重要である
7 e all practise selective attention. Without it, we wouldn't be able to deal with the bombardment of sensory information that continually comes our way. Right now, for example, are you aware of your feet in your shoes? The wristwatch on your arm? No doubt, you have just become aware of this sensory information as your attention has been drawn to it. Selective attention is an essential survival skill, but its downsides can be complacency and the inattention that develops when our levels of vigilance fall.

As English language teachers, it is incumbent upon us to actively and continually draw our learners' attention to those aspects of English that differ from their established languages. Many subtle, but vital, differences may have been consciously (or unconsciously) selected out by our learners' well-established linguistic filters. For learners to fully come to grips with a new language, they must remain alert (and be kept alert) to those linguistic features that may not be highly significant in their established languages. This is especially pertinent when it comes to new and different sounds. Learners need to be aware of the temptation to apply the sound patterns of their dominant language to the new one.

Well-developed phonemic awareness skills have been widely recognised as an important precursor to English language literacy (Moats, 2000; Stanovich, 1986). Learners who possess both letter knowledge and phonemic awareness skills can readily move into sounding out letter combinations in order to read both real and invented words. They can also break down the words they hear into separate sounds for spelling. Such learners will have learned to tune in to the smallest sounds in the English language, and they will have some awareness of the direct links between letter combinations and sounds. Snowling (2019) described such a readiness for further reading development as "alphabetic competence" (p. 15). 
Phonemic Awareness

Phonemic awareness is the most finely tuned level of a range of phonological awareness skills that span being able to separate streams of spoken English into ever-decreasing units of auditory perception. These include noticing individual words in sentences, separating the syllables within individual words, and becoming aware of the phonemes inside syllables. Phonemic awareness is an understanding that spoken words and syllables are made up of sequences of speech sounds and an ability to manipulate these sounds in spoken words (Yopp, 1992). It is a set of analytical skills that operates on sounds as distinct from meaning. An example of a phonemic awareness task might be to identify the first sound in fish (a real word) or the final sound in plog (a nonword). Unfortunately, it is not always easy to detect single phonemes in any language as they are run together (or coarticulated) in spoken words and syllables.

Most people are not necessarily "tuned-in" to the phonemic level of their primary language (Moats, 2000, p. 7). We have all grown so used to the sounds of our own established languages that these have become automated. In other words, we all practise a form of selective attention, which allows us to concentrate on other aspects of our language, such as meaning and nuance. When it comes to literacy, however, we need to reacquaint ourselves with these units of sound and learn to align them with the writing system that has been designed for our language over time. In English, reading involves translating printed symbols into spoken sounds. This process is called decoding and its mirror image, translating spoken words into printed symbols, involves encoding (or spelling). Learning to read and write is not natural (Adams, 1990). In evolutionary terms, we do not have dedicated brain structures that are set up to process the printed word. Literacy requires explicit instruction and well-developed auditory and articulatory skills. A new language (and a new written script) will need time and strategic instruction to become fully embedded in its learners' brains, as different writing systems may require new and different neural networks to come into play (Perfetti \& Dunlap, 2008, p. 30).

The English language has approximately 44 different phonemes (20 vowel sounds and 24 consonant sounds), but it is quite unusual in having a large number of vowel sounds and two forms of the uncommon th sound (Dryer \& Haspelmath, 2013). According to the World Atlas of Language Structures, the average number of distinctive speech sounds (i.e., phonemes) in any one of the world's languages is somewhere between 25 and 30 (Dryer \& Haspelmath, 2013).

Student-learners of any new language (as opposed to those who have been raised as bi- or multilinguals) will inevitably have to deal with the challenges of both perceiving and producing a new range of sounds. It has been claimed that language learners whose established language has fewer phonemes than the target language may be less sensitive to the phonetic subtleties of the new language (McBride-Chang et al., 2008). When it comes to English language literacy, it has been repeatedly shown that strong phonemic awareness skills are excellent predictors of future success in reading (Melby-Lervåg, Lyster, \& Hulme, 2012; Simmons \& Kameenui, 1998).

\section{A "Blindspot" in TESOL}

Over the past three decades, within English language circles in English-dominant countries, a great deal has been made of the central importance of phonological skill development to alphabetic reading skills. By now, the so-called reading wars have been fought and won (Castles, Rastle, \& Nation, 2018; Moats, 2007), and the minor skirmishes that remain tend to revolve around methodological issues and exactly what constitutes an effective phonics program. When it comes to the international TESOL (Teaching English to Speakers of Other Languages) industry, however, the deep and highly significant phonological challenges posed by this language and its alphabetic writing system remain something of a "blindspot" (Bunce, 2017, p. 77). Today, as a consequence of rapid globalisation, the TESOL industry serves a student body that is vastly different from its 20th-century beginnings with European sojourners in the U.K. and Hispanicheritage learners in the U.S.A. (Koda \& Zehler, 2008). The vast majority of today's learners come from countries that use quite different writing systems. It is no longer the case that first-language literacy skills can be easily transferred across to alphabetic-scripted English, as many have claimed (Bunce, 2016b; Share, 2014).

TESOL's near-total reliance on its long-standing partnerships with large publishing houses is, in fact, a further impediment to progress in this important area, as both industries remain caught in a 20th-century paradigm of making alphabetic assumptions regarding today's English language learners. Share (2014) has called out such biases in both research and teaching practices as alphabetism and Anglocentricities. He pointed out that a lot of English-language researchers leave out the words "in English" in their research results and subsequent claims, unlike other researchers who are obliged to qualify their findings by adding "in Chinese/Arabic/Korean." This extends to the use of alphabetic terminology to describe units of language as letters or words or even parts of the brain (e.g., "letterbox area," Dehaene, 2009). He goes so far as to suggest that the very notion of the phoneme may be an "artifact of Western European literacy" (Share, 2014, p. 2).

Given that so many of today's English learners will be new to alphabetic skills, there is an urgent need for more targeted teaching materials that introduce the alphabetic principle (Byrne, 1998) in formats that are better suited to older learners with established 
literacy skills in non-Romanised or nonalphabetic scripts. Such learners will require not only phonological insights, but also efficient handwriting skills and a heightened awareness of English word-building patterns (i.e., morphology; Bunce, 2016a).

\section{A Suggested Sequence for Teaching Phonological Skills}

Phonological awareness work should be carried out in the complete absence of the printed word. Given that so many overseas English language learners have, no doubt, already embarked on their learning journey without a full mastery of phonological insights into English, they may well need to do some unlearning and relearning. Phonological awareness work can be tiring, and is best done in bursts of 10 minutes or so at the start of lessons (Adams, 1990; Schuele \& Murphy, 2014) as well as incidentally during lessons whenever an interesting word appears in print (e.g., Close your books. Let's listen really closely to this word ...).

1. Strictly speaking, even though phonemic awareness is concerned with the tiniest of sounds, it is important for learners to first become aware of the nature of English syllables, for they are the home of the phoneme. Syllables are relatively easy to detect as they are built around the beat of a vowel sound. Many Asian languages and their scripts operate at the level of the syllable, however, the majority of these may be openended syllables. English, by contrast, has close to $50 \%$ closed syllables: syllables that end in a consonant sound. As vowel sounds are open-mouthed sounds, learners can count how many syllables there are in longer words by placing their hands beneath their chins and feeling their jaws drop as they say the core vowel sound. An initial awareness of syllables is essential in learning to manage longer words, both orally and in print. It is important to make sure that students are constantly aware of English syllable closures, particularly the plural sounds /s/,/z/ and /əz/. Also practise closing real and invented syllables with different consonants: all orally, no print. It will soon become obvious which closures are familiar to the learners and which are not. Use these activities:

Hands under your chins. How many syllables in ... (a range of words)?

I want you to add /t/ to close these syllables: po-, nu-, go-, . . (a range of open syllables).

2. Most syllables can be broken down into onset and rime combinations: the onset being the initial consonant (or consonant blend) sound(s) and the rime being the vowel sound plus any final consonant sounds. In the word pool, for example, $/ \mathrm{p} /$ is the onset and /ool/is the rime. The words rain and pain share the same rime/phonogram (-ain). A list of rimes (or phonograms) can be a handy resource. An awareness of onsets and rimes is an important step between identifying syllables and segmenting these syllables into phonemes (Treiman \& Zukowski, 1996). Words that share rimes will rhyme. Gather sets of minimal pairs and ask students if the two words rhyme. They could all point to the words Yes or No, written on either side of the whiteboard. By watching their gestures, it is easy to notice which students are rhyme aware. A more challenging extension would be to present three words and ask the group which one is the odd-one-out, in terms of rhyme (see Appendix). It is not a good idea, however, to ask English language learners to generate their own rhymes, as one might do with young native speakers. Rhyme generation requires a very large vocabulary and a daily familiarity with common rhyming games. This can be really difficult in a new language.

A lot of phonological awareness activities involve the use of minimal pairs of words. When saying them, try pretending to yourself that there is an imaginary third (or fourth) word in the sequence. This will go some way to halting any natural tendency to add a rising or a falling tone: something that will be highly distracting to speakers of tonal languages such as Chinese, Vietnamese, or Thai. When searching for sets of minimal pairs online, try using the search terms articulation or speech sounds to find the huge sets of contrasting words that are regularly used by speech therapists. If learners are well advanced in their knowledge of English spelling, or are teachers in training, try using a few nonwords at all stages in this instructional sequence. This will push learners to hone their finer listening skills.

3. The next step is to drill down inside syllables to isolate their component phonemes This is the realm of true phonemic awareness. Seidenberg (2018,) amusingly calls activities at this level "Finding Phonemo" (p. 50). Using lists of simple, monosyllabic CVC (consonant-vowel-consonant) English words, students can be asked to identify the first, middle, or final sounds that they hear-not the letter names, but the sounds. How will they produce these sounds? It is important to point out that consonant sounds can be either voiced or unvoiced. It doesn't really matter if we can hear the student at the back of the class saying $/ \mathrm{p} /$ or $/ \mathrm{t} /$, as long as we can see it. As instructors, we should also be careful not to turn single phonemes into syllables by adding an unnecessary /uh/, such as /puh/ for /p/ or /tuh/ for /t/. Keep the sounds clipped short and voiceless when needed. Gradually, this activity can progress to monosyllabic 
words with consonant clusters (or blends) such as /tr/ or /st/. These clusters can be found in both the initial and the final positions of words and syllables, and they can be a real stumbling block for many English-language learners. Here, students can be asked to isolate the second or the second-last sounds in words such as flat and post and nonwords such as brin or dest (See Appendix). Later on, using polysyllabic words, these isolation skills can be brought to bear within the separated syllables.

4. Once sounds can be isolated within syllables, learners can be asked to segment and count the number of sounds in words of varying lengths. Here, all literate learners will be sorely tempted to imagine the words' spelling, so a good dose of nonwords can be added to the mix. As this stage of awareness raising will, undoubtedly and importantly, overlap with instruction in written sound-letter correspondences, it is important to draw the distinction between "How many sounds?" and "How many letters?" This is the point at which learners should begin to experience a kind of alphabetic awakening, as they begin to see how the alphabetic code works. Such a realisation is absolutely vital for learners whose first languages are written in scripts with few direct indicators of sounds, such as Chinese and Japanese kanji. Such learners have learned to visually memorise hundreds of written symbols, and they may even have learned all their English words as visual units rather than as sets of encoded sounds (Bunce, 2012). It is vital that written English words begin to speak to such students.

5. The most challenging levels of phonemic awareness activities are those that require English learners to manipulate individual phonemes. In these activities, students will need to hold the given words (or nonwords) in their short-term memories and adjust them in some way-by deleting, adding, or substituting phonemes. Some examples will make these activities clear:

The word is lawn. Cut off the / $\mathrm{n} /$ sound. What do you have? The word is plan. Cut out the /l/ sound. What do you have? The word is lock. Add $/ k /$ sound at the start. What do you have? The word is head. Cut out the /e/ sound and put in /a/. What do you have?

These activities can grow into a guided-listening form of word ladders, with one change in sound following on from another, for example, moving from the word spring to summer via string, sting, sing, sling, slim, slimmer, and simmer. Online word ladder puzzles for children can easily be adapted into such single-sound manipulation exercises.

Regular, short bursts of any kind of phonological manipulation activities that are paired with the oral production of the words (or syllables or sounds) involved can all contribute to raising our learners' awareness of the smallest units of language that are well hidden in the continuous stream of human speech (Ehri \& Nunes, 2002).

\section{Some Recommendations}

First, it is important for English language teachers to be well-informed regarding the sound systems of their learners' primary languages and the ways in which these may differ from English. Equally important, and too often overlooked, is some basic familiarity with the nature of the learners' writing systems and the ways in which sounds are represented (or not) in the written scripts that these learners have grown up using. Learning a new orthography will place a different set of cognitive demands on its learners. For example, eye movements may need time to adjust to elongated letter-sequences (i.e., words), and even the presence of spaces between such words will be new to some (Chen, Song, Lau, \& Wong, 2003).

Second, the bi- or triscriptal learner of English will need an investment of extra time and direct instruction in the phonemic-level code of the English alphabetic system. Without such insights, many learners might simply superimpose their established language-learning styles onto the English written script and completely miss the magic of the alphabetic code in its direct capture of the sounds of the language. Teachers of English will themselves need to be fully informed and capable of working imaginatively with the 44 phonemes in the English sound system and their translations into the English written code.

Institutions that teach English to biscriptal learners need to build more time into their various bridging courses to be certain that their learners have achieved a sufficient level of alphabetic fluency before they embark on higher studies that will be delivered in English. The self-teaching nature of alphabetic reading, in which readers are able to independently acquire and increase their own vocabulary (Share, 1995), will be a great help in carrying them through the veritable tsunami of academic vocabulary that awaits them. No amount of memorisation can compete with the value of knowing that they have the decoding and encoding skills that alphabetic competency gives them.

Third, in order to conduct daily bursts of phonological awareness activities, instructors do not need to invest in expensive commercial programs or textbooks. Nor do they 
need to worry too much about keeping to a particular sequence of activities. Sound work is already sound teaching. There is no golden sequence, and phonemic awareness instruction does not need to be lengthy or laboured to be effective (Ehri \& Nunes, 2002)

A useful toolkit for teachers might include some or all of the following resources: a ready source of minimal pairs of words, some sets of simple nonwords, a list of common phonograms, lists of monosyllabic words with target-sound combinations, and some word ladder puzzles. A wall chart of the 44 sounds of English paired with 44 key words would also make an important, easy reference point in every language classroom.

Finally, there is a need for TESOL teachers to directly confront the ill-informed alphabetism of many educational publishing houses and the stranglehold that they appear to have on university-level teaching materials. In a 2019 interview, the acclaimed applied linguist, Henry Widdowson, opined that, "the publishers tell us what we are to teach, basically, and what research we should do" (Hemmi, Mackenzie, \& Yokomoto, 2019 , p. 12). This commercially driven, and rather unfortunate, nexus between publishers and professors needs to be challenged.

\section{Conclusion}

It is now time for a paradigm shift in English language teaching: one that fully acknowledges, and fully serves, the pressing needs of its 21 st century, multiscripted learners. Globalisation has brought all manner of different-scripted learners into English language classrooms, and their established literacy skills and insights demand both recognition and respect. Just as translanguaging pedagogy openly welcomes the presence of learners' spoken languages, so too should classroom displays and written activities recognise our learners' different writing systems. This will not only serve to highlight the various ways in which the world's written scripts operate, it will also provide opportunities for learners to compare and contrast these with the English alphabetic system.

As English learners gradually come to grips with the underlying principles of the alphabetic code and as they learn to isolate and manipulate the individual sounds in the language and link these to various spelling options, new words will begin to speak to biscriptal learners of the language. It is absolutely essential that the self-teaching nature of being able to read in an alphabetic script be revealed to its newest learners (Share, 1995).

\section{Bio Data}

Dr. Pauline Bunce is a highly experienced teacher of English and humanities subjects. She has taught adolescent and adult learners in Sri Lanka, Brunei Darussalam, Malaysia, and Hong Kong, as well as her native Australia. She has written and presented widely regarding the highly practical, yet frequently overlooked, skills and insights into English phonology, morphology, and handwriting that all biscriptal learners of this alphabeticscripted language require for efficient English language literacy. < paulinebunce@hotmail. com>

\section{References}

Adams, M. J. (1990). Beginning to read: Thinking and learning about print. Cambridge, MA: MIT Press.

Bunce, P. (2012). Alphabet headaches: The bi-literacy challenge for Chinese students. TESOL in Context, Special Edition S3. Retrieved from https://independent.academia.edu/PaulineBunce/ Papers

Bunce, P. (2016a). According to the script: A handbook for biscriptal learners of English. Self-published. Available from www.alphabetheadaches.com/Bookstore.html

Bunce, P. (2016b). The English alphabet: Alpha-best or alpha-beast? In P. Bunce, R. Phillipson, V. Rapatahana, \& R. Tupas (Eds.), Why English? Confronting the Hydra (pp. 142-153). Bristol, England: Multilingual Matters.

Bunce, P. (2017). Biscriptal English learners: A "blindspot" in global English-language teaching. In M. Borjian (Ed.), Perspectives on language and globalisation: An autoethnographical approach (pp. 77-89). New York, NY: Routledge.

Byrne, B. (1998). The foundation of literacy: The child's acquisition of the alphabetic principle. London, England: Psychology Press.

Castles, A., Rastle, K., \& Nation, K. (2018). Ending the reading wars: Reading acquisition from novice to expert. Psychological Science in the Public Interest, 19(1), 5-51. https://doi.org/10.1177/1529100618772271

Chen, H-C., Song, H., Lau, W. Y., \& Wong, K. F. E. (2003). Developmental characteristics of eye movements in reading Chinese. In C. McBride-Chang, \& H-C. Chen (Eds.), Reading development in Chinese children. Westport, CT: Praeger Press.

Dehaene, S. (2009). Reading in the brain. New York, NY: Penguin Books.

Dryer, M. S., \& Haspelmath, M. (Eds.). (2013). The world atlas of language structures online. Leipzig Germany: Max Planck Institute for Evolutionary Anthropology. Retrieved from http://wals.info 
Ehri, L., \& Nunes, S. R. (2002). The role of phonemic awareness in learning to read. In A. Farstrup \& S. J. Samuels (Eds.). What research has to say about reading instruction (3rd ed.; pp. 110-139). Newark, DE: International Reading Association.

Hemmi, C., Mackenzie, G., \& Yokomoto, K. (2019). An interview with Henry Widdowson. The Language Teacher, 43(6), 10-12. https://doi.org/10.37546/JALTTLT43.6-3

Koda, K., \& Zehler, A. M. (Eds.) (2008). Learning to read across languages: Cross-linguistic relationships in first- and second-language literacy development. New York, NY: Routledge.

McBride-Chang, C., Tong, X., Shu, H., Wong, A. M.-Y., Leung, K.-W., \& Tardif, T. (2008). Syllable, phoneme, and tone: Psycholinguistic units in early Chinese and English word reading. Scientific Studies of Reading, 12, 171-194. https://doi.org/10.1080/10888430801917290

Melby-Lervåg, M., Lyster, S. A., \& Hulme, C. (2012). Phonological skills and their role in learning to read: A meta-analytic review. Psychological Bulletin, 138, 322-352.

https://doi.org/10.1037/a0026744

Moats, L. C. (2000). Speech to print: Language essentials for teachers. Baltimore, MD: Paul H. Brooks.

Moats, L. C. (2007). Whole-language high jinks: How to tell when "scientifically-based reading instruction" isn't. Thomas B. Fordham Institute. Retrieved from https://files.eric.ed.gov/fulltext/ED498005.pdf

Perfetti, C. A., \& Dunlap, S. (2008). Learning to read: General principles and writing systems variations. In K. Koda \& A. M. Zehler (Eds.), Learning to read across languages: Cross-linguistic relationships in first- and second-language literacy development (pp. 13-38). New York, NY: Routledge.

Schuele, C. M., \& Murphy, N. D. (2014). The intensive phonological awareness program. Maryland, MD: Paul H. Brookes.

Seidenberg, M. (2018). Language at the speed of sight: How we read, why so many can't, and what can be done about it. New York, NY: Basic Books.

Share, D. (1995). Phonological recoding and self-teaching: Sine qua non of reading acquisition. Cognition, 55(2), 151-218. https://doi.org/10.1016/0010-0277(94)00645-2

Share, D. (2014). Alphabetism in reading science. Frontiers in Psychology, 5, 752. https://doi.org/10.3389/fpsyg.2014.00752

Simmons, D. C., \& Kameenui, E. J. (Eds.) (1998). What reading research tells us about children with diverse learning needs: Bases and basics. Mahwah, NJ: Erlbaum.

Snowling, M. J. (2019). Dyslexia: A very short introduction. Oxford, England: Oxford University Press.

Stanovich, K. E. (1986). Matthew effects in reading: Some consequences of individual differences in the acquisition of literacy. Reading Research Quarterly, 21, 360-405.
Treiman, R., \& Zukowski, A. (1996). Children's sensitivity to syllables, onsets, rimes, and phonemes. Journal of Experimental Child Psychology, 61, 193-215. https://doi.org/10.1006/jecp.1996.0014

Yopp, H. K. (1992). Developing phonemic awareness in young children. The Reading Teacher, 45, 696-703. Retrieved from https://www.jstor.org/stable/20200960

\section{Appendix}

\section{A Sequence of Phonological Skills}

1. Syllables - counting, reversing and closing

Hands under your chins. How many syllables in ... (a range of words)?

Compound nouns-reverse the syllables, e.g., sunset to set-sun, headache to achehead etc.

Closing open syllables-Close these syllables with / $\mathrm{t}$ [ [or any consonant sound]. The teacher says po-, ku-, ba-, mi-, se-, etc. [any open-ended syllables]. Learners repeat with the new ending.

2. Onset and rime-same or different? Signs: YES and NO on the board.

Do these words rhyme? Learners point.

Odd one out. First, second, or third?

man-can, cup-pup, fig-fix, etc.

bat-cat-man, gate-beat-feet, dog-figfog, etc.

3. Identifying single sounds in $\mathrm{CVC}$ words

CVC words-same or different? How? Where? pat-pan, cot-hot, net-net, man-men

What is the first sound in ...? What is the final sound in ...? What is the middle sound in ...?

4. Segmentation-counting sounds (not letters) in CVC, CCVC, CVCC and CCVCC words How many sounds do you hear?

Words with and without blends pot, bat, hut, chat, move, bent, shout, thing, stump, etc. 
5. Manipulation of single sounds

The word is man. Cut off the $/ \mathrm{m} /$ [or the $/ \mathrm{n} /$ ] sound. What do you have?

The word is park. Add /s/ to the start [or end]. What do you have?

The word is top. Cut off the $/ \mathrm{t} /$ [or $/ \mathrm{p} /$ ] and replace it with $/ \mathrm{m} /$. What do you have? Word ladders: The word is spring $>$ replace $/ \mathrm{p} /$ with $/ \mathrm{t} />$ string $>$ take out the $/ \mathrm{r} />$ sting $>$ take out the $/ \mathrm{t} />$ sing $>$ add $/ \mathrm{l} /$ after $/ \mathrm{s} />$ sling $>$ replace $/ \mathrm{ng} /$ with $/ \mathrm{m} />$ slim $>$ add $/$ er/ to the end $>$ slimmer $>$ take out the $/ \mathrm{l} />$ simmer $>$ replace $/$ i/ with $/ \mathrm{uh} />$ summer 